\title{
Through the Looking Glass: Examining Theory Development in Project Management WITH THe ResOURCE-BASEd VieW LeNS
}

KAM JUGDEV, Athabasca University, 8311-11 Street SW

Calgary, Alberta, Canada T2V 1N7

\begin{abstract}
Project management is a young discipline and young disciplines tend to lack welldeveloped theories. This paper examines several topics that help with theory development - the use of a common terminology and holistic frameworks, the importance of avoiding tautologies, and the merits of analogies. To guide the process, the paper draws from a recent empirical study that used the ResourceBased View to study project management as a strategic asset. The paper discusses how these four topics that contribute to theory development were managed in the study. Applying theory construction practices enables us to be more aware of the challenges related to research and improves our understanding of variables as used in conceptual and empirical papers. By applying the Resource-Based View to project management, the paper also shows how we can improve our understanding of project management as a source of competitive advantage.
\end{abstract}

Keywords: Resource-Based View; strategy; theory construction; project management; competitive advantage

(1)2004 by the Project Management Institute Vol. 35 , No. 3, 15-26, ISSN $8756-9728 / 03$

\begin{abstract}
Introduction
Globally, companies are increasingly relying on project management to help them complete projects more efficiently and effectively (Cleland \& Ireland, 2002; Project Management Institute, 2000). Although project management has been around unofficially since time immemorial when people started to coordinate tasks and activities with each other (e.g., from building shelters to ships to pyramids), it is a young discipline (Verzuh, 1999). Evolving disciplines, such as project management, often lack a fully developed theoretical base and tend to draw from more established fields. As is often heard, "There is nothing more practical than a good theory" (Meredith, 2002, p. 47). But what does this mean and how is this relevant to project management?

This paper begins with a brief overview of the perceived state of theory development in project management. Then, the paper examines some concepts related to theory construction with an emphasis on several topics that help develop theories - the use of a common terminology and frameworks, avoiding tautologies, and the merits of analogies. Thereafter, the paper introduces readers to the Resource-Based View of the firm. The issue is that project management has not been studied using the Resource-Based View and the dimensions of a strategic asset in the discipline remain to be understood. This is an important topic because it will help us understand the facets of project management that lead to or contribute to a competitive advantage, so that companies can invest in the appropriate practices and develop those internal assets relevant to positioning project management strategically. This paper examines steps taken to study project management using the Resource-Based View lens. It discusses some of the theory development issues encountered and explains how they were managed. The paper concludes with summary comments on theory development in project management.
\end{abstract}

\section{Project Management}

Project management evolved in the 1950s from mathematical research based on algorithms and project planning techniques (e.g., network planning efforts involving Program Evaluation and Review Techniques and Critical Path Methods) (Engwall, 2003; Packendorff, 1995). Over the years, a stream of literature developed in operations management and was devoted to computer applications and 
expert systems for project planning, control, and risk analysis (Packendorff, 1995). The planning approach was criticized in the 1960 s for an overemphasis on the rationalistic approach, and this gave rise to a body of literature on project organizational structures and project leadership. A number of the emerging areas of study in project management are based on theories from management and focus on such topics as human resources, organizational change, quality, and business process reengineering (Kloppenborg \& Opfer, 2002; Ulri \& (llri, 2000). However, a recent scientometric study of project management for the 1987-1996 period of over 3,565 articles indicated that the primary areas of publication continue to be in the technical domains of operations research, cost engineering, business process reengineering, and infrastructure (Ulri \& Ulri, 2000). Kloppenborg and Opfer's assessment of the project management literature identified over 19,000 books on project management within the 1960-1999 timeframe (Kloppenborg \& Opfer, 2002). The project management textbooks tend to focus on normative advice on planning and managing projects and the systems approach leads to viewing project management as simply a tool based on rationalistic views (Morris, 2001a).

In the United States, the Project Management Institute first developed A Guide to the Project Management Body of Knowledge (PMBOK ${ }^{\circledR}$ Guide) in 1976. The PMBOK ${ }^{\circledR}$ Guide emphasizes time, cost, and scope, and uses a systems approach based on inputs, processes, and outputs. Over the years, revisions to the $P M B O{ }^{\circledR}$ Guide did not change the structure of the body of knowledge, nor did the revisions introduce or support the need for a project management theoretical foundation. Nonetheless, the $P M B O K^{\circledR}$ Guide continues to be put forth as the "generally accepted" project management practices to its over 130,000 members (Project Management Institute, 2000, p. 3). Similar bodies of knowledge were developed by the Association of Project Management in England and variations evolved in Austria, France, Germany, Switzerland, and the Netherlands (IPMA, 2000; Morris, 2001a, 2001b). The various bodies of knowledge address professional qualifications and competences, but do not address project management in terms of a theoretical base. It would be beneficial for a holistic body of knowledge to address the importance of theory development to the discipline and make efforts to delineate these theories.

As most of the project management knowledge is based on practitioner-driven normative approaches, there is a need for a theory in the discipline (Engwall, 2003; Packendorff, 1995). "Most descriptive research on the management of projects is relatively young and suffers from a weak theoretical basis" (Engwall, 2003, p. 792). "Descriptive empirical research grounded in theoretical problems is rare" (Packendorff, 1995, p. 325). Recently, there have been calls for better theory generation in project management (Engwall, 2003; Meredith, 2002; Morris, 2001a; Packendorff, 1995). Others have made this same criticism over the years and the Project Management Journal ${ }^{\circledR}$ is cur- rently conducting a self-review to seek ways of improving its academic quality.

Meredith recently assessed papers published in the Project Management Journal from 1995-2001 (Meredith, 2002). In his critique, Meredith categorized the Project Management Journal articles in terms of high, medium, and low rigor. $63 \%$ of the Project Management Journal articles were deemed to be of low methodological rigor and only $3 \%$ of the articles fit the high rigor category. Assessments of this nature raise the question of how we can improve theory development and research within project management. The two go hand-in-hand as a study's theoretical underpinning helps shape the research question and, in turn, the methodology used. In his assessment, Meredith indicated that the tutorial, background, and war story approaches are not recognized as research methodologies (Meredith, 2002). He further explains that research involves the use of a good literature review to describe and understand phenomena followed by an examination of cause-and-effect relationships. Then, research builds on the literature and models to develop frameworks that address the issue of "why." "Frameworks are essentially pre-theories" that are then tested (Meredith, 2002, p. 48).

The above overview relates to the question of why we need good theory in project management. Theories help us advance the body of knowledge. Rigorous research encourages the use of evidence-based practice (Meredith, 2002) and can better position project management as a valueadding practice with enhanced credibility.

\section{Some Concepts from the Philosophy of Science: What is Theory?}

In general terms, a theory is a description of a new idea or phenomenon, supported with empirical evidence, and described in ways that others understand it. Theories are important because they help explain and predict events, patterns, and trends. Theories go beyond descriptions and debunk common stereotypes and myths. Theories also help develop and refine bodies of knowledge (Olszewski-Walker \& Coalson-Avant, 1995). In this section, the paper briefly introduces readers to several definitions of theories and research epistemologies. Then, the paper discusses how models (paradigms) help with theory construction, the challenges of working with partial theories, the importance of avoiding tautologies in partial theories, and the value of analogies to help explain concepts in partial theories.

Theories can be defined in specific or broad ways. Specific definitions limit the term to the natural sciences, and involve empirical verifications based on direct observation and experience as per the laws of physics (Herzog, 1996). For example, Kerlinger defines a theory as "a set of interrelated constructs (variables), definitions, and propositions that presents a systematic view of phenomena by specifying relationships among variables, with the purpose of explaining natural phenomena" (Kerlinger, 1973, p. 64). However, a broader definition states that scientific knowledge is a typology to organize things, explain past events 
and predict future events, explain or help with understanding event causes, and potentially control events (Reynolds, 1971). A definition of theory from the social sciences states that theory is narrative and describes social process (DiMaggio, 1995). Such more-inclusive definitions are applicable to the types of studies conducted in the social and management sciences, including project management.

Theory development also involves different ontologies and research epistemologies. Ontology has to do with the nature of reality regarding the phenomenon researchers seek to understand. Ontological perspectives can range from objective worldviews supporting one reality to subjective worldviews supporting multiple realities. For example, the scientific approach supports one worldview (or world truth), whereas phenomenological studies, which are qualitative in nature, involve multiple realities as presented by the various participants. Epistemology has to do with the study of knowledge, that is, how we know what we know. The long-standing epistemological debate on how to conduct research is rooted in two different inquiry paradigms.

"Logical-positivism, which uses quantitative and experimental methods to test hypothetical-deductive generalizations, versus phenomenological inquiry, using qualitative and naturalistic approaches to inductively and holistically understand human experience in context-specific settings" (Patton, 1990, p. 37).

Research epistemologies also describe the relationship of the researcher to subjects. In the positivist approach (as per the scientific approach), the researcher is distant and independent (or objective, context-free, and deductive) of the subjects. In contrast, within the phenomenological paradigms, the researcher interacts more with those being researched (Cresswell, 1998), and the approach is viewed as subjective, contextual, and inductive. For example, in ethnographic studies, the research is viewed as "insider" fieldwork and the researcher interacts more with the participants (Patton, 1990).

During theory development, models (paradigms) evolve and help refine the theories. Paradigms are collections of shared beliefs. Some theoretical ideas are known as radical changes in orientation or Kuhn's paradigms to connote revolutionary changes. To exemplify, Newtonian physics explains how planets orbit the sun, whereas quantum physics explains how electrons surround the nucleus of an atom. The shift from Newtonian physics to quantum physics was a Kuhn's paradigm because the common laws of physics did not apply at the atomic level. Less radical changes in orientation may involve refinements to detail and can be called paradigm variations (Reynolds, 1971). Mature sciences, such as the natural sciences, tend to have well-developed paradigms as per the laws of physics. As the social sciences are evolving, they typically lack well-developed paradigms or theories (Chalmers, 1999). Instead, evolving disciplines tend to have perspectives that are in the theory development stages. For example, the Resource-Based
View is a perspective from strategy with its roots in industrial organization economics (Conner, 1991).

Another aspect of theory building has to do with tautologies. Tautologies involve circular reasoning. 'Tautologies lack empirical content and some view them to be conceptual problems that arise primarily in partial theories (Arend, 2003; Fahy, 2000; Powell, 2001; Priem \& Butler; 2001b). Tautologies are helpful, though, because they engender debate on the theoretical perspective, challenge researchers to revisit their methodologies, and bring to the forefront issues that need to be researched to advance theories and perspectives.

Theories do not have to be complete to make significant contributions to knowledge (Herzog, 1996). Even partial explanations are appropriate, since they serve as "pieces of the puzzle" towards theory construction. Inlike studies based on developed theories, where hypotheses are used to test "if/then" relationships, researchers frequently use propositions when the theoretical underpinning of the study involves a perspective. Propositions allow researchers to examine relationships that may not be of the causal nature. Propositions can be thought of as hunches or ideas and are appropriate to use with perspectives where research on the relationships between variables is evolving (Reynolds, 1971).

Partial explanations tend to lack a clear consensus on terminology and concepts. Such terminology issues can be problematic in developing a common understanding. In addition, researchers may not always consider the work others have done. This can make it difficult for researchers and readers to grasp how the terms relate to each other and can hinder theory development. Debate, discussion, and further building on ideas put forth by others help develop theory, and can lead to consensus on terms and concepts. For example, well-developed literature reviews and meta-analyses extend our understanding of the prevailing ideas on specific topics and work done to date.

The process of theorizing involves simultaneous activi ties of abstracting, generalizing, relating, selecting, explaining, synthesizing, and idealizing (Weick, 1995). 'These activities contribute to the creation of reference lists, data, variable lists, diagrams, and hypotheses. Although Sutton and Staw (1995) reject these activities as non-theory, Weick (1995) argues that these practices help build theory because they help create frameworks that show relationships, develop concepts and the interconnections between them, and enable researchers to look at alternative explanations. Arnoult (1976) identifies four characteristics of a good theory:

- Testability refers to a theory that clearly ascertains wrong predictions

- Power means that the theory correctly explains a variety of phenomena

- Fertility means that the theory offers new ideas to explore further

- A simple theory is elegant and parsimonious; it involves few concepts and relationships. 
These characteristics can be considered the gold standard for theories, and are equally relevant to the social sciences as they are to the natural sciences.

On the continuum of scientific to social science approaches to theory development, there is no one right way to develop theory, but there are many different and acceptable ways of doing so, and many studies involve both quantitative and qualitative methods (Chalmers, 1999; Cresswell, 1994, 1998; Denzin, 1996; Hardy \& Clegg, 1997; Mason, 1998; Maxwell, 1996; Reynolds, 1971; Wacquant, 1993; Weick, 1995). Although there are different viewpoints on the concept of theory, as well as research paradigms, there is agreement that a theory explains phenomena and the properties involved. It is important to be aware of the different ways in which reality can be construed and knowledge created as individual worldviews and beliefs influence our approaches to theory development. Appraising a theory or perspective through different worldview lenses helps us see its various facets.

"Perspectives or views need not be complete theories in order to contribute to our understanding of strategic management" (Priem \& Butler, 2001a, p. 32). The ResourceBased View is one such perspective and is gaining increasing. attention within strategy. The next section introduces the Resource-Based View of the firm. This sets the stage to discuss the topics related to theory development that were encountered and addressed in the empirical study on project management.

\section{The Resource-Based View of the Firm}

Strategy is a vast field with a rich theoretical and empirical base.

\begin{abstract}
"It's a field where everything matters. Choices matter, the leader matters, the culture matters, the values mattex, random events matter, and so on. Strategy is inherently an integrative subject that has to allow for complexity" (Argyres \& McGahan, 2002, p. 52).
\end{abstract}

Within strategy, the competitive advantage literature is increasingly important as compressions of distance and time intensify competition and focus managerial attention on multiple internal and external factors (Thomas, Pollock, \& Gorman, 1999). To outperform rivals, firms must deliver greater value to customers or create comparable value at a lower cost (Porter, 1996). Firms must make choices in areas such as products, services, goals, and industry positioning, to name a few. In practical terms, strategic management is about "the direction of organizations" and deals with competition and firm success and failure (Rumelt, Schendel, \& leece, 1994, p. 9). Firm performance depends on a number of factors including those factors external to the company, such as the macro-economic environment (Porter, 1996) and those internal to it, such as the company's internal assets and management practices (Barney, 2002). The perspective of looking at factors external to the firm is called the Industry View and the perspective of examining factors within the firm is called the Resource-Based View.
The Industry View looks to the marketplace to help firms determine the areas in which they want to compete (Andrews, 1980). Porter introduced the industry-focused strengths, weaknesses, opportunities, and threat model, along with the five structural forces techniques that can erode a firm's long-term industry average profitability (Porter, 1991). 'The five forces are threats of new entrants, bargaining power of suppliers, rivalry among existing competitors, bargaining power of buyers, and threats of substitute products or services (Collis \& Montgomery, 1995; Porter, 1991). The Industry View is a good ex-post description of market conditions and allows firms to identify some of the conditions for normal rent returns, but does not provide information on above-normal profits (Chakraborty, 1997). The Industry View downplays resource heterogeneity and immobility, which are two key tenets of examining competitive advantage in terms of a firm's internal assets (Amit \& Schoemaker, 1993; Barney, 1991). In contrast, the Resource-Based View underscores the need for a balanced approach to competitive advantage involving a firm's strengths and weaknesses, along with industry components (Barney \& Zajac, 1994). In the Resource-Based View, companies focus on their asset mix (organizational, physical, financial, human, and social assets) and determine which ones they should develop and invest in further and which ones to de-emphasize.

A crucial question in the strategy literature asks, "Why do firms differ?" In contrast to the Industry View that emphasizes the environment, the Resource-Based View explains firm existence based on internal assets that are scarce, difficult to trade, imitate, appropriate, and give a firm its competitive advantage (Amit \& Schoemaker, 1993; Madhok, 2002; Porter, 1991). The Resource-Based View emphasizes the creation, maintenance, and renewal of a competitive advantage through a firm's unique resources, their characteristics, and how they change over time (Foss, 1997; Schulze, 1994). According to Barney, a strategic asset is characterized by being valuable, rare, inimitable, and having an organizational focus, otherwise known as the VRIO framework (Barney, 2001). According to Barney, a firm needs four attributes for a sustained competitive advantage. In his original framework, Barney indicated that resources must be valuable, rare, inimitable, and non-substitutable (VRIN) (Barney, 1991). In a later model, Barney revised the framework and replaced the term "non-substitutable" with "organizational focus," which referred to managerial support (Barney, 1998; Chakraborty, 1997).

A firm's strategic assets may not always be visible; examples of strategic assets include quality, reputation, managerial skills, brand recognition, patents, culture, technological capability, customer focus, and superior managerial skills (Barney \& Zajac, 1994; Castanias \& Helfat, 1991; Chakraborty, 1997; Hawawini, Subramanian, \& Verdin, 2002; Kogut \& Zander, 1993). A firm's formal processes and production functions are the backbones that support strategic assets, and firms protect their assets through business practices. Strategic assets are unique to the firm. Strategic 
assets signify complex, higher order interactions between resources, processes, and knowledge (Eisenhardt \& Martin, 2000; Grant, 1991; Henderson \& Cockburn, 1994; Kaplan, Schenkel, von Krogh, \& Weber, 2001; Kogut \& Zander, 1992; Liedtka, 1996; Teece, Pisano, \& Shuen, 1997). Strategic assets involve a mix of explicit and tacit knowledge that is embedded in a company's unique internal skills, knowledge, and resources (Foss, 1997; Rumelt et al., 1994). Such strengths are difficult to purchase, let alone copy, so they can contribute to a firm's ability to move beyond competitive convergence toward a competitive advantage or strategic position. Other synonyms for strategic assets include core competences (Prahalad \& Hamel, 1990), distinctive competence (Selznick, 1957), dynamic capability (Teece et al., 1997), dynamic routines (Collis, 1991), indivisible assets (Teece, 1980), integrative capabilities, implicit / social knowledge, meta-capability (Kaplan et al., 2001), organizational architecture (Henderson \& Cockburn, 1994), and organizational capability. However, the distinctions between these terms are not always obvious.

Within the Resource-Based View literature, there is a lack of clarity on resource characteristics that help develop versus sustain a competitive advantage (Amit \& Schoemaker, 1993; Barney, 1991, 1998; Chakraborty, 1997; Collis \& Montgomery, 1995; Grant, 1991; Mata, Fuerst, \& Barney, 1995; Peteraf, 1993; Priem \& Butler, 2001a). For example, Amit and Schoemaker view scarcity as a sustaining feature, but Barney and Peteraf view it as a feature that develops a competitive advantage. As these distinctions can be confusing, I decided to use Barney's VRIO framework because it covers the main characteristics of strategic assets addressed in the literature and has been used for empirical studies (Barney, 1991, 1998, 2002; Ray, Barney, \& Muhanna, 2004). The VRIO concepts are presented in the following table.

\begin{tabular}{|c|c|c|c|c|c|}
\hline Valuable? & Rare & $\begin{array}{l}\text { Difficult to } \\
\text { Imitate? }\end{array}$ & $\begin{array}{l}\text { Supported by } \\
\text { Organization? }\end{array}$ & $\begin{array}{l}\text { Competitive } \\
\text { Implications }\end{array}$ & Performance \\
\hline No & - & - & & $\begin{array}{l}\text { Competitive } \\
\text { Disadvantage }\end{array}$ & Below Normal \\
\hline Yes & No & - & & Competitive Parity & Normal \\
\hline Yes & Yes & No & & $\begin{array}{l}\text { Temporary Competitive } \\
\text { Advantage }\end{array}$ & Above Normal \\
\hline Yes & Yes & Yes & & $\begin{array}{l}\text { Sustained Competitive } \\
\text { Advantage }\end{array}$ & Above Normal \\
\hline
\end{tabular}

Table 1: VRIO Framework (adapted from Barney, 1998)

If a resource is only valuable in the VRIO framework, it leads to competitive parity. Both value and rarity are required for a temporary competitive advantage and value, rarity, and inimitability are required for a sustained competitive advantage (Barney, 1998). An organizational focus is necessary to both develop a competitive advantage and sustain it (Barney, 1998).

An extensive literature review did not indicate that project management had been assessed with the Resource-Based View, and only one article discussed project management in terms of core competences (DeFillippi \& Arthur, 1998). The Resource-Based View is appropriate to use as a theoretical underpinning for project management for several reasons. First, the Resource-Based View has a rich 20-year history of development that includes the VRIO framework. Second, the Resource-Based View addresses knowledge and process assets and this fits with the exploration of project management as a complex resource. The Resource-Based View has relevance to project management because it emphasizes the less tangible human and organizational assets that also involve social and intellectual capital (knowledge, skills, and know-how) (Lundvall \& Johnson, 1994). Finally, one way of achieving theory status is to conduct studies with perspectives in the theory construction stage.

\section{Examining Theory Development in Project Management with the Resource-Based View Lens}

In 2003, I completed an empirical study on how companies develop and sustain project management as a strategic asset (Jugdev, 2003). The study began with an extensive literature review of several fields - project management, strategy, and the Resource-Based View. This led me to appreciate the complexities of the Resource-Based View and to better understand the difference between a theory and perspective. The literature review enabled me to develop two research questions to investigate - what characterizes project management when it is considered a strategic asset, and how do firms develop and sustain a competitive advantage in project management? The literature review and understanding of this key concept enabled me to translate the concept into constructs for which data was gathered using a case study approach.

The multiple case study explored the characteristics of a strategic asset in project management and the processes companies use to develop and sustain the advantage. The study involved four international companies from the financial, telecommunications, manufacturing, and utility industries. Senior, middle, and project managers from the companies participated in interviews and a survey. Sixtyseven interviews were conducted and 28 responses to a project management maturity survey were analyzed. The qualitative data was coded and textually analyzed using Atlas.ti ${ }^{\circledR}$ software and the survey results were analyzed using non-parametric tests with SPSS ${ }^{\circledR}$ software.

Initially, I considered using project management maturity models to assess project management within companies as a source of competitive advantage. The project management maturity models are based on the Carnegie-Mellon Software Engineering Institute's Capability Maturity Model for software development (Carnegie-Mellon, 2002). The models consist of five linear stages reflecting software processes and practices that are increasingly more defined and repeatable. The five levels are: Level 1: Initial Process; Level 2: Structured Process and Standards; Level 3: Organizational Standards and Institutionalized Process; Level 4: Managed Process; Level 5: Optimizing Process (Pennypacker, 2001). The software development maturity models are based on a theoretical foundation of software process improvement and total quality management 
(Ngwenyama \& Nielsen, 2003), yet others argue that the models are atheoretical (Carnegie-Mellon, 2002; Dymond, 1995). The models use a technical, rational, and mechanis tic view of organizations because they do not address the social aspects of companies (Ngwenyama \& Nielsen, 2003).

The project management maturity models address tangible assets, but not intangible assets (knowledge assets). The models do not emphasize organizational processes and practices. The models typically lack a connection between operations management and strategy. Few project management maturity models have been empirically tested and many are based on anecdotal material, case studies, or espoused best practices (LSI-International, 2001; Hartman \& Skulmoski, 1998; MicroFrame, 2001; Pennypacker, 2001; Schlichter, 2000; Skulmoski, 2001). In addition, as these models do not draw from the economic or strategy literature on competitive advantage, or meet the VRIO criteria, the arguments put forth towards winning in the marketplace with such models are weak at best (Jugdev \& Thomas, 2002). Consequently, I turned to the Resource-Based View as a theoretical underpinning for the study.

The study brought to light several issues in terms of the ory development including the need for common terminology, the importance of an accepted framework, tautologies, and the value of an analogy to show connections between constructs.

\section{Creating a Common Terminology to Help Build Theory}

A perspective differs from a theory in that it still involves issues of terminology and concept confusion, whereas a theory has generally addressed many of these concerns. Terminology issues are common in theory construction and reflect an ongoing exploration of conceptual frameworks (Shaw \& Gaines, 1995). Terminology issues were evident in the Resource-Based View. For example, when it comes to the word "resource," some authors use the term to refer to tangible assets and others use it to refer to both tangible and intangible assets. Barney (2001) describes resources as all the firm's assets, capabilities, competencies, organizational processes, firm attributes, information, and knowledge, while Schulze (1994) defines resources as "the set of assets and skills which are employed to create and support a competitive advantage" (p. 37). Some researchers interpret resources as basic building blocks (assets, inputs, primary resources), and others view them as more complex combinations (e.g., resource bundles, complementary assets, strategic assets, stocks, competences, capabilities, meta-capabilities, and routines) (Foss, 1997).

The literature also uses different terms to describe tangible and intangible resources, and not all authors distinguish between the two. Some group resources as tradable and non-tradable assets (Dierickx \& Cool, 1989). Non-tradable assets (i.e., reputations, dealer loyalty, trust, and knowhow) cannot be bought or sold and are non-transferable or non-appropriable (Kogut \& Zander, 1993). They are in fixed supply, and build up over time through training and learning as successful strategies are implemented. Non-tradable assets are viewed as sources of durable firm heterogeneity and are known as "sticky" resources because of their close connections to the firm or person (Collis, 1994; Grant, 1991; Priem \& Butler, 2001a). In other words, they cannot be exchanged like commodities, but can offer social benefits or costs (Tcha, 1997). The Resource-Based View literature also involves many synonyms for strategic assets, as mentioned earlier.

The literature review confirmed the lack of consensus regarding terminology within the Resource-Based View, and this enabled me to develop an extensive table on the synonyms and terms used for tangible resources, intangible resources, and isolating or protective mechanisms, identify who coined certain terms, and refine my understanding of the terms. The review confirmed that my understanding was evolving as I encountered other publications with similar frameworks once I had completed mine (Fahy, 2000).

Although Barney states that "distinctions among resources, capabilities, and competencies can be drawn in theory, it is likely that they will become badly blurred in practice" (Barney, 2001, p. 157). Such terminology issues can be problematic in developing a common understanding among scholars and must be addressed as part of developing theory. Further research, debate, and dialogue can help explore such issues and eventually lead to disentangling terminology issues. On this basis, I decided to use the words "resource" and "asset" as synonyms and used the term "strategic asset" to encompass the synonyms for this term in the literature. Since completing the strategic asset study and in discussions with other academics in strategy, I am further refining my understanding that perhaps in project management, we should use the term "meta-resource" until we have a more solid base of empirical studies supporting it as a strategic asset.

The breadth of terms used in the Resource-Based View underscores the importance of a common language, as it was sometimes a difficult perspective to understand. With an appreciation of some of the concepts from philosophy of science, I was able to understand the rationale for using propositions and not hypotheses. Propositions examine relationships that may not be of the causal nature.

Propositions are like hunches or ideas and are appropriate to use with perspectives where research on the relationships between variables is evolving (Reynolds, 1971). I also learned the importance of conducting a thorough literature review. This helped me understand the breadth and depth of publications on the Resource-Based View, the degree to which theories relevant to the topic have been developed, the extent of empirical studies in the field, and it improved my understanding of the issues that are being debated. The array of Resource-Based View terms used in the literature also reflected the need for a holistic resource framework.

\section{Developing Frameworks to Help Build Theory}

Theory building involves creating reference lists, data, variable lists, diagrams, and frameworks (Weick, 1995). The 
Resource-Based View provides evidence of the use of frameworks. Within the perspective, resource frameworks show preliminary groupings of elements in a logical order and depict how various components fit into an overall structure. The resource frameworks map components into an organized and logical whole to explain phenomena. Some examples of resource groupings include physical, organizational, human, social, financial, technological, and intangible assets (Barney, 1991, 1998; Brush, Greene, Hart, \& Haller, 2001; Marino, 1996; Thomas et al., 1999). Other examples of groupings in the Resource-Based View literature focus on grouping assets hierarchically, such as in the pyramid of value creation. The pyramid of value creation involves generic resources at the base, followed by core competences, and strategic assets at the apex (Brush et al., 2001).

A review of the literature involved an assessment of some of the Resource-Based View frameworks used to explain how firms develop and sustain a competitive advantage (Amit \& Schoemaker, 1993; Barney, 1991, 1998; Chakraborty, 1997; Collis \& Montgomery, 1995; Grant, 1991; Mata et al., 1995; Peteraf, 1993; Priem \& Butler, 2001a). The resource frameworks covered the breadth of characteristics deemed relevant in developing and sustaining a competitive advantage including valuable (important), rare (unique), inimitable (difficult to copy), organizational focus (management support), low-tradable (non-transferable), durable (long-lasting), and non-substitutable (nothing comes close to replacing a certain resource). Most of the authors consistently cited inimitability in their frameworks.

Surprisingly, there was a lack of consensus among the authors on the relative use of the array of Resource-Based View characteristics. The resource characteristics that some authors identified as helping develop a competitive advantage were viewed by others as sustaining a competitive advantage. In addition, few authors discussed organization focus as explicitly as Barney did $(1991,1998,2002)$. On this basis, I was able to focus on the VRIO framework with confidence, as it has been extensively developed and empirical studies conducted with it. The VRIO framework served as the basis for the research methodology for the strategic asset study on project management. It guided the development of the semi-structured interview instrument to explore the two research questions on project management as a strategic asset.

In terms of radical or less dramatic theoretical ideas, the VRIO framework is a paradigmatic variation of the Resource-Based View as it involves refinements to details (Reynolds, 1971). It took a decade or so to develop the VRIO framework. Like one piece of the puzzle, the VRIO framework is a contribution toward the efforts of other researchers to develop the Resource-Based View and adds to our understanding of strategic assets. In terms of the merits of frameworks, I was able to appreciate that when frameworks (such as the VRIO framework) have been developed and are used repeatedly, it makes sense to conduct further studies using them, rather than proposing dramatic changes without an empirical basis of support.
In addition to terminology issues and the need for a holistic framework, some perspectives often involve tautology issues. In the course of the strategic asset study, I encountered some readings on tautology issues and these are discussed next.

\section{Avoiding Tautology Traps to Help Build Theory}

Within the Resource-Based View, strategic assets are often described as being valuable, rare, inimitable, and having an organizational focus (Barney, 2002). A tautology may exist within the Resource-Based View if a competitive advantage is defined in terms of value and rarity, and the same terms are used as the resource characteristics (Barney, 2001). A tautology can be avoided if resource characteristics are defined independent of firm performance so that empirical falsification is possible. Another way of dealing with tautology issues is to develop proxy variables.

As evident from debates such as those between Priem and Butler and Barney, the tautology issue in the ResourceBased View continues to gain prominence (Barney, 2001; Priem \& Butler, 2001a). Priem and Butler argued that Barney's 1991 publication on the Resource-Based View in the Journal of Management was tautological. This may be the case, but Barney's contributions have helped advance the Resource-Based View, and those that conducted empirical studies thereafter were more cautious about how they defined resource variables independent of firm performance. Barney continues to be a noted authority on the Resource-Based View.

As scholars grapple with theoretical concepts and the challenges of operationalizing them, they often discuss tautologies and ways in which they can be avoided. These discussions reflect different views on how tautologies are defined and are useful in helping scholars revisit how Resource-Based View terms are operationalized. The discussions also heighten awareness on key issues within the perspective. Dealing with tautologies will help develop the Resource-Based View according to Arnoult's characteristics of a good theory having increased testability (Arnoult, 1976). Over time, a simple and elegant theory of the Resource-Based View may emerge.

The tautology issue was circumvented in the strategic asset study as it was an exploratory study that did not strive to measure a dependent variable (such as superior performance), but focused instead on the range of independent variables (antecedents) such as resource characteristics and organizational practices that potentially contribute to a competitive advantage.

The strategic asset study resulted in a rich dataset of qualitative findings on the main constructs and has brought me to the point now where I can focus on a quantitative study that builds on the first study. The next research project (which is currently underway) involves operationalizing the VRIO constructs with a survey to assess the extent to which project management is a meta-resource within companies in North America. This study will use two dependent variables - firm performance and project management performance. 
The study is being structured to avoid the tautology trap, as the measures for the independent and dependent variables will not be the same.

Firm performance has long been assessed using financial and economic measures. Performance has many meanings and can be assessed with long versus short and financial versus relationship building approaches (Deshpande, Farley, \& Webster, 1993). I plan to use a combination of financial and subjective measures. Various databases offer company financial data and I can also measure firm performance with Likert scale questions asking participants to assess their company on profitability, size, market share, and growth rate in comparison to the largest competitors for that particular business (Deshpande et al., 1993).

However, using a highly aggregate dependent variable, such as firm performance, may not be the optimal way of examining the Resource-Based View and could lead to misleading conclusions, so some recommend the use of less aggregate (intermediate) variables (Ray et al., 2004). As a result, I plan on using project management performance as another dependent variable. This variable will be assessed using the VRIO framework. The findings from the prior study from four international companies enabled me to operationalize the VRIO concepts and awareness on tautologies; such experience is enabling me to avoid this trap in the upcoming empirical study. To summarize, when working with complex perspectives such as the Resource-Based View, frameworks and tautologies help elucidate component parts and interrelationships. Another way of understanding complex topics within theory development involves the use of analogies.

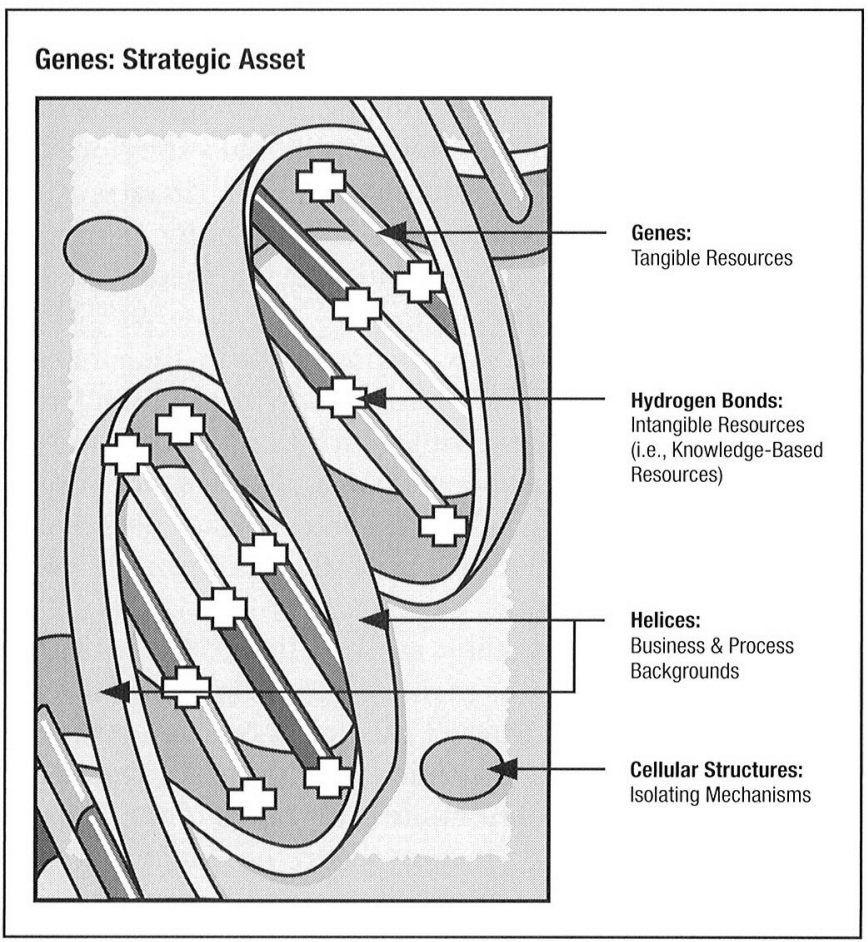

Figure 1: Strategic asset genome

\section{Developing Analogies to Help Build Theory}

Based on Arnoult's system of classifying theories into one of four categories - metaphors, analogies, reductionist (simpler) concepts, and abstract (mathematical) relationships, the strategic asset study made use of the analogical approach (Arnoult, 1976). The use of metaphors, similes, and analogies is helpful in theory development because they encourage thinking in different ways and draw on symbolic constructs to help explain reality (Tsoukas, 1991). Metaphors, similes, and analogies are not widely used in the natural sciences where theories are well developed.

Metaphors, similes, and analogies help us make inferences about something that we know less about on the basis of what we know of other things. In the project management study, a genome analogy was used to depict the strategic asset genome and this is discussed next.

Just as scientists around the world are working to crack the biochemical code for each chromosome to determine human characteristics, strategy and economics researchers are working to unlock the code for competitive advantage creation (Boulton, 2000). Unlocking the genome of a company's competitive advantage involves defining, grouping, and characterizing the component parts used to develop a competitive advantage. Figure 1 portrays this analogy.

Within cells of complex organisms, the nucleus consists mainly of the chromosome (genome) that carries the genetic information within the genes, and cellular structures that power chemical reactions. In humans, the chromosomes consist of thousands of genes made up of deoxyribonucleic acid (DNA).

In turn, each DNA structure consists of chemical nucleotide bases linked by hydrogen bonds. The chromosome is like a twisted stepladder or helix, with the genetic information located on the rungs (genes) (DNASciences, 2003). Although the genes are an important building block, the chromosome, as a whole, is vital in passing on the genetic code to the next generation. As well, the hydrogen bonds may appear to be nondescript and secondary, but they are crucial in how the DNA nucleotide bases combine with each other. Understanding how all the genetic components interact is paramount to breaking the genetic code.

By using an analogy, some of the earlier concepts of the Resource-Based View may be easier to understand, as well as the relationships among them. In relating the genome to the strategic asset genome, a firm's tangible resources are analogous to the vast number of genes. The business and process backbones within the firm are like the helix. They support strategic assets through decisions, organizational policies, procedures, and practices to create products and services (Brush et al., 2001). Capabilities, competences, and routines are knowledge assets and are analogous to the gene's hydrogen bonds. They hold the tangible resource genes together and are crucial in creating strategic assets. $\Lambda$ kin to cells protecting their genomes through cellular structures and processes, firms protect their assets through isolating 
mechanisms such as history and causal ambiguity. The strategic assets are equivalent to the chromosomes. Strategic assets are as unique to each firm as a genetic blueprint for reproduction is to each person. Additional parallels between the human and strategic asset genome follow:

- Just as the human genome consists of more genes than chromosomes, a firm's genome consists of more resources than strategic assets.

- Iust as individuals differ in their genetic makeup, so do organizations and their resource mix; some assets are also more important than others.

- Although the chromosome is ultimately more important than the individual genes for reproductive purposes, it requires the genes and hydrogen bonds. Similarly, strategic assets are more important than individual resources, but basic resources are essential in creating strategic assets.

- Just as chemistry determines how the DNA bases bond specifically to certain bases through hydrogen bonds, a company's intangible resources (invisible assets, capabilities, routines, processes, or competences) are like knowledge bonds that serve a similar function. They are vital in linking resources and creating meta-resources.

- Similar to the human genome involving long DNA strands that comprise chromosomes, a firm's formal processes and production functions are the backbones supporting strategic assets.

- Just as cells protect their genome with cellular structures and chemical processes, firms protect assets from being copied by rivals through isolating mechanisms (i.e., history, causal ambiguity, and social complexity).

- As part of evolution, the genetic code passes from parents to offspring (e.g., hair color, eye color, and other traits). Similarly, a firm's strategic assets (chromosomes) characterize its strengths and can be passed to spin off companies, joint ventures, and partnerships.

Taking this analogy one step further helps us understand project management in terms of the genome analogy. The following is a brief excerpt of findings from the strategic asset study, reflecting practices that make project management valuable, rare, inimitable, and with an organizational focus.

- As a knowledge-based discipline, project management consists of tangible assets (genes) such as tools, techniques, templates, methodologies, and other forms of explicit knowledge called "know-what."

- In terms of project management business and process backbones (helices), the strategic asset study identifies the use of leadership and solid support for the discipline, the establishment of organization-wide project management programs, continuous improvement practices, and connections between project management and business outcomes, as examples of management practices supporting the discipline.

- The intangible resources (hydrogen bonds) within project management are evident in such practices as staff embracing the discipline, clear links between the organizational and project management cultures, and staff sharing tacit knowledge or "know how," through social capital practices.

- Regarding isolating mechanisms (cellular structures), there is evidence that companies that view and support project management as a strategic asset experienced periods of stabilization in the history of how the discipline evolved. One company went from "project management strength to strength" over a 20 year period. There were also indications that the discipline involved social complexity. The financial institute exhibited the strongest profile of project management as a strategic asset and it capitalized on its knowledge-sharing practices. It had a better appreciation of the importance of social capital as a way of sharing tacit knowledge.

To summarize, I used the VRIO framework to empirically examine project management as a strategic asset. I had developed the analogy in the course of data analysis. As I reviewed the data for different themes, the analogy helped me further examine aspects of intangible assets within project management. The genome analogy helped depict the connections between the various components of the Resource-Based View and helped portray the constructs in relation to project management. The analogy was also useful because it drew my attention to the importance of intangible assets (hydrogen bonds) in project management. What was striking about the value of the analogy was that it did not simply depict the relationships between the genome and strategic asset. Instead, the analogy also focused my attention on what appears to be a small aspect of the diagram - the hydrogen bonds. The hydrogen bonds are almost invisible, yet vital to how the genome functions. Similarly, intangible assets seem to be undervalued in project management, yet they potentially play a crucial role in project management as it is a knowledge-based discipline, and tacit knowledge and social capital are significant sources of knowledge exchange. The theme of intangible assets is emerging as a crucial component of the current study I am working on, whereby I am assessing both the tangible and intangible assets in project management and their connections to project management as it meets the Resource-Based View criteria of being valuable, rare, inimitable, and having an organizational focus. In particular, my focus will be on tacit knowledge and social capital in project management.

\section{Conclusions}

Developing good theory takes time and is an incremental process. This paper examined the topics of a common terminology, frameworks, tautologies, and analogies in relation to theory construction. The paper used some lessons learned from a prior empirical study to exemplify how these theory development concepts were used.

The Resource-Based View is work in progress towards a 
holistic theory. Over 100 articles are published on this perspective each year (Rouse \& Daellenbach, 2002). More recently, an increasing number of publications are taking empirical approaches to the Resource-Based View (Castanias \& Helfat, 2001; Collis, 1991; Cool \& Schendel, 1987; Henderson \& Cockburn, 1994; Levinthal \& Myatt, 1994; Lopez, 2001; Montealegre, 2002; Ray et al., 2004; Wiggins \& Ruefli, 2002). This groundswell of support and research will help raise awareness of the contributions being made to the field, foster idea sharing, and encourage researchers to build on previous works. Over time, a clearer and more complete picture of the Resource-Based View perspective will emerge.

In parallel, we can capitalize on the advances made within the Resource-Based View. We can continue to do research on project management using the Resource-Based View lens. By doing so, we can contribute to knowledge development in project management and strategy. By examining project management with the Resource-Based View lens, we can develop a clearer picture of the characteristics of project management that contribute to a competitive advantage and better understand the connections between project management and strategy.

\section{References}

Amit, R., \& Schoemaker, P. J. H. (1993). Strategic assets and organizational rent. Strategic Management Journal, 14(1), 33-46.

Andrews, K. (1980). The concept of corporate strategy. In N. Foss (Ed.), Resources, firms, and strategies: A reader in the resourcebased perspective (1st ed., Vol. 1, pp. 52-59). Oxford, UK: Oxford University Press.

Arend, R. J. (2003). Revisiting the logic and research considerations of competitive advantage. Strategic Management Joumal, 24(3), 279-284.

Argyres, N., \& McGahan, A. M. (2002). An interview with Michael Porter. Academy of Management Executive, 16(2), 43-52.

Arnoult, M. D. (1976). Fundamentals of scientific method in psychology ( 2 ed.). Dubuque, IN: William C. Brown.

Barney, J. B. (1991). Firm resources and sustained competitive advantage. Journal of Management, 17(1), 99-120.

Barney, J. B. (1998). On becoming a strategic partner: The role of human resources in gaining competitive advantage. Human Resource Management, 37(1), 31-46.

Barney, J. B. (2001). Is the resource-based "view" a useful perspective for strategic management research? Yes. Academy of Management Review, 26(1), 41-56.

Barney, J. B. (2002). Gaining and sustaining competitive advantage (2nd ed.). Upper Saddle River, NJ: Prentice-Hall, Inc.

Barney, J. B., \& Zajac, E. J. (1994). Competitive organizational behaviour: Toward an organizationally-based theory of competitive advantage. Strategic Management Journal, 15(1), 5-9.

Boulton, R. E. S. (2000). A business model for the new economy. The Journal of Business Strategy, 21(4), 29-35.

Brush, C. G., Greene, P. G., Hart, M. M., \& Haller, H. S. (2001). From initial idea to unique advantage: The entrepreneurial challenge of constructing a resource base. The Academy of Management Executive, 15(1), 64-78.

Carnegie-Mellon. (2002, November 15). Carnegie Mellon Software Engineering Institute: Capability maturity models. Retrieved November 20, 2002, from http://www.sei.cmu.edu/cmmi/
Castanias, R. P., \& Helfat, C. E. (1991). Managerial resources rents. Journal of Management, 17(1), 155-171.

Castanias, R. P., \& Helfat, C. E. (2001). The managerial rents model: Theory and empirical analysis. Journal of Management, 27(6), 661-678.

Chakraborty, K. (1997). Sustained competitive advantage: A resource-based framework. Advances in Competitiveness Research, $5(1), 32-63$.

Chalmers, A. F. (1999). What is this thing called science? (3rd ed.). Indianapolis, IN: Hackett Publishing Company Inc.

Cleland, D. I., \& Ireland, L. (2002). Project management: strategic design and implementation (4th ed. Vol. 1). New York: McGraw-Hill.

Collis, D. J. (1991). A resource-based analysis of global competition: The case of the bearings industry. Strategic Management Journal, 12(Summer, special issue), 49-68.

Collis, D. J. (1994). Research note: How valuable are organizational capabilities? Strategic Management Joumal, 15(1), 143 152.

Collis, D. J., \& Montgomery, C. A. (1995). Competing on resources: Strategy in the 1990s. Harvard Business Review, 73(4), 118-128.

Conner, K. R. (1991). A historical comparison of resourcebased theory and five schools of thought within industrial organization economics: Do we have a new theory of the firm? Journal of Management, 17(1), 121-154.

Cool, K. O., \& Schendel, D. E. (1987). Strategic group formation and performance: The case of the U.S. pharmaceutical industry, 1963-1982. Management Science, 33(9), 1102-1124.

Cresswell, J. W. (1994). Research design: Qualitative \& quantitative approaches. Thousand Oaks, CA: Sage Publications, Inc.

Cresswell, J. W. (1998). Qualitative inquiry and research design: Choosing among five traditions. Thousand Oaks, CA: Sage Publications, Inc.

DeFillippi, R. J., \& Arthur, M. B. (1998). Paradox in projectbased enterprise: The case of film making. California Management Review, 40(2), 125-139.

Denzin, N. K. (1996). The epistemological crisis in the human disciplines: Letting the old do the work of the new. In R. Jessor, A. Colby \& R. A. Shweder (Eds.), Ethnography and human development: Context and meaning in social inquiry (pp. 127-151). Chicago: University of Chicago Press.

Deshpande, R., Farley, J. U., \& Webster, F. E. (1993). Corporate culture, customer orientation, and innovativeness in Japanese firms: A quadrad analysis. Journal of Marketing, 57(1), 23-27.

Dierickx, I., \& Cool, K. (1989). Asset stock accumulation and sustainability of competitive advantage. Management Science, 35(12), 1504-1514

DiMaggio, P., J. (1995). Comments on "What theory is not". Administrative Science Quarterly, 40(3), 391-397.

DNASciences. (2003, January 25). DNA Sciences Inc. Retrieved January 21, 2003, from http://www.dna.com/home/home.jsp?jsession$\mathrm{id}=1150011043159995906 \& l i n k=$ Home.htm

Dymond, K. M. (1995). A guide to the CMM: Understanding the capability maturity model for software. Retrieved November 20 , 2002, from http://home.okstate.edu/homepages.nsf/ toc/level2.info.book1.html

Eisenhardt, K. M., \& Martin, J. A. (2000). Dynamic capa- 
bilities: What are they? Strategic Management Journal, 21(10-11), 1105-1121

Engwall, M. (2003). No project is an island: Linking projects to history and context. Research Policy, 32(5), 789-808.

ESI-International. (2001, November 22). ESI-International. Retrieved November 20, 2002, from http://www.esi-intl.com/

Fahy, J. (2000). The resource-based view of the firm: Some stumbling-blocks on the road to understanding sustainable competitive advantage. Journal of European Industrial Training, $24(2 / 3 / 4), 94-104$

Foss, N. J. (Ed.). (1997). Resources, firms, and strategies: A reader in the resource-based perspective (1st ed. Vol. 1). Oxford, UK: Oxford University Press

Grant, R. M. (1991). The resource-based theory of competitive advantage: Implications for strategy formulation. California Management Review, 33(3), 114-135.

Hardy, C., \& Clegg, S. (1997). Relativity without relativism: Reflexivity in post-paradigm organization studies. British Journal of Management, 8(Special Issue), S5-S17.

Hartman, F. T., \& Skulmoski, G. (1998). Project management maturity. Project Management, 4(1), 74-78.

Hawawini, G., Subramanian, V., \& Verdin, P. J. (2002). Is performance driven by industry - or firm-specific factors? A new look at the evidence. Strategic Management Journal, 24(1), 1-16.

Henderson, R., \& Cockburn, I. (1994). Measuring competence? Exploring firm effects in pharmaceutical research. Strategic Management Joumal, 15(1), 63-84.

Herzog, T. R. (1996). Research methods in the social sciences (1st ed.). New York: Harper Collins College Publishers.

IPMA. (2000, Nov 20). IPMA Certification. Retrieved December 27, 2002, from http://www.ipma.ch/site/certification.htm

Jugdev, K. (2003). Developing and sustaining project management as a strategic asset: A multiple case study using the resourcebased view. Unpublished doctoral dissertation, University of Calgary.

Jugdev, K., \& Thomas, J. (2002). Project management maturity models: The silver bullets of competitive advantage. Student paper award. Project Management Journal, 33(4), 4-14.

Kaplan, S., Schenkel, A., von Krogh, G., \& Weber, C. (2001). Knowledge-based theories of the firm in strategic management: $A$ review and extension (MIT Sloan Working Paper No. 4216-01).

Kerlinger, F. N. (1973). Foundations of behavioral research (2 ed. Vol. 1). New York: Holt, Rinehart \& Winston.

Kloppenborg, T., \& Opfer, W. (2002). The current state of project management research: Trends, interpretations, and predictions. Project Management Journal, 33(2), 5-18.

Kogut, B., \& Zander, U. (1992). Knowledge of the firm, combinative capabilities, and the replication of technology. In N. Foss (Ed.), Resources, firms, and strategies: A reader in the resource-based perspective (1st ed., Vol. 1, pp. 306-325). Oxford, UK: Oxford University Press.

Kogut, B., \& Zander, U. (1993). Knowledge of the firm and the evolutionary theory of the multinational corporation. Journal of International Business Studies, 24(4), 625-644.

Levinthal, D. A., \& Myatt, J. (1994). Co-evolution of capabilities and industry: The evolution of mutual fund processing Strategic Management Journal, 15(1), 45-62.

Liedtka, J. M. (1996). Collaborating across lines of business for competitive advantage. The Academy of Management
Executive, 10(2), 20-46.

Lopez, V. A. (2001). An overview review of the resourcebased view (RBV) of the firm, drawing on recent Spanish management research. Irish Journal of Management, 22(2), 105-120.

Lundvall, B. A., \& Johnson, B. (1994). The Learning Economy. Journal of Industry Studies, 1(2), 23-42.

Madhok, A. (2002). Reassessing the fundamentals and beyond: Ronald Coase, the transaction cost and resource-based theories of the firm and the institutional structure of production. Strategic Management Journal, 23(6), 535-550.

Marino, K. E. (1996). Developing consensus on firm competencies and capabilities. The Academy of Management Executive, $10(3), 40-50$.

Mason, J. (1998). Qualitative research (1st ed. Vol. 1). London: Sage Publications, Inc.

Mata, F. J., Fuerst, W. L., \& Barney, J. B. (1995). Information technology and sustained competitive advantage: A resourcebased analysis. MIS Quarterly, 19(4), 487-507.

Maxwell, J. A. (1996). Qualitative research design: An interactive approach (1 ed. Vol. 41). Thousand Oaks, CA: Sage Publications, Inc

Meredith, J. R. (2002, July). Developing project management theory for managerial application: The view of a research journal's editor. Paper presented at the Frontiers of Project Management Research and Application, Seattle, WA.

MicroFrame. (2001, October 1). Project management maturity model. Retrieved November 20, 2002, from http://www.microframe.com/

Montealegre, R. (2002). A process model of capability development: Lessons from the electronic commerce strategy at Bolsa de Valores de Guayaquil. Organization Science, 13(5), 514531.

Morris, P. W. G. (2001a). Science, objective knowledge, and the theory of project management. Unpublished manuscript, London.

Morris, P. W. G. (2001b). Updating the project management bodies of knowledge. Project Management Journal, 32(3), 21-30.

Ngwenyama, O., \& Nielsen, P. A. (2003). Competing values in software process improvement: An assumption analysis of CMM from an organizational culture perspective. IEEE Transactions on Engineering Management, 50(1), 100-112.

Olszewski-Walker, \& Coalson-Avant. (1995). Strategies for theory construction in nursing (3rd ed. Vol. 1). Norwalk, CT: Appleton \& Lange.

Packendorff, J. (1995). Inquiring into the temporary organization: New directions for project management. Scandinavian Journal of Management, 11(4), 319-333

Patton, M. Q. (1990). Qualitative evaluation and research methods (2nd ed.). Newbury Park, CA: Sage Publications, Inc.

Pennypacker, J. (2001). Project management maturity benchmark: A Center for Business Practices (CBP) research report (Published manuscript). Havertown, PA: Project Management Solutions, Inc.

Peteraf, M. (1993). The cornerstones of competitive advantage: A resource-based view. In N. Foss (Ed.), Resources, firms, and strategies: A reader in the resource-based perspective (1st ed, Vol. 1, pp. 187-203). Oxford, UK: Oxford University Press.

Porter, M. E. (1991). Towards a dynamic theory of strategy. Strategic Management Joumal, 12(5), 97-117.

Porter, M. E. (1996). What is strategy? Harvard Business 
Review, 74(6), 61-78.

Powell, T. C. (2001). Competitive advantage: Logical and philosophical considerations. Strategic Management Journal, 22(9), 875-888.

Prahalad, C. K., \& Hamel, G. (1990). The core competence of the corporation. In N. Foss (Ed.), Resources, firms, and strategies: A reader in the resource-based perspective (1st ed., Vol. 1, pp. 235-256). Oxford, UK: Oxford University Press.

Priem, R. L., \& Butler, J. E. (2001a). Is the resource-based "view" a useful perspective for strategic management research? Academy of Management Review, 26(1), 26-40.

Priem, R. L., \& Butler, J. E. (2001b). Tautology in the resource-based view and the implications of externally determined resource value: further comments. Academy of Management Review, 26(1), 57-66.

Project Management Institute. (2000). A guide to the project management body of knowledge (PMBOK Guide) 2000 ed. Newtown Square, PA: Project Management Institute.

Ray, G., Barney, J. B., \& Muhanna, W. A. (2004). Capabilities, business processes, and competitive advantage: Choosing the dependent variable in empirical tests of the resource-based view. Strategic Management Journal, 25(1), 23-37.

Reynolds, P. D. (1971). A primer in theory construction (1st ed.). New York: MacMillan Publishing Company.

Rouse, M. J., \& Daellenbach, U. S. (2002). More thinking on research methods for the resource-based perspective. Strategic Management Journal, 23(6), 963-967.

Rumelt, R. P., Schendel, D. E., \& Teece, D. J. (1994). Fundamental issues in strategy. In R. P. Rumelt, D. E. Schendel \& D. J. Teece (Eds.), Fundamental issues in strategy (pp. 9-47). Cambridge, MA: Harvard Business School Press.

Schlichter, J. (2000). Personal communication. Newtown Square, PA: Project Management Institute.

Schulze, W. S. (1994). Two resource-based theories of the firm: Definitions and implications. In P. Schrivistava, A. Huff \& J. E. Dutton (Eds.), Advances in Strategic Management (Vol. 10, pp. 127-151). New York: JAI Press.

Selznick, P. (1957). Leadership in administration: A sociological interpretation. In N. Foss (Ed.), Resources, firms, and strategies: A reader in the resource-based perspective (1st ed., Vol. 1, pp. 21-26). Oxford, UK: Oxford University Press.
Shaw, M. L. G., \& Gaines, B. R. (1995, November 24). Comparing conceptual structures: Consensus, conflict, correspondence, and contrast. Retrieved February, 2002, from http://ksi.cpsc.ucalgary.ca/articles/KBS/COCO/

Skulmoski, G. (2001). Project maturity and competence interface. Cost Engineering, 43(6), 11-19.

Sutton, R. I., \& Staw, B. M. (1995). What theory is not. Administrative Science Quarterly, 40(3), 371-384.

Tcha, M. (1997, November 15). Externality and protection: Online international trade policy course. Retrieved November 20, 2002, from http://www.firststep.com.au/econ/plain/externalities.html

Teece, D., J., Pisano, G., \& Shuen, A. (1997). Dynamic capabilities and strategic management. Strategic Management Journal, 18(7), 509-533.

Teece, D. J. (1980). Economies of scope and the scope of the enterprise. In N. Foss (Ed.), Resources, firms, and strategies: A reader in the resource-based perspective (Vol. 1, pp. 103-116). Oxford, UK: Oxford University Press.

Thomas, H., Pollock, T., \& Gorman, P. (1999). Global strategic analysis: Frameworks and approaches. The Academy of Management Executive, 13(1), 70-82

Tsoukas, H. (1991). The missing link: A transformational view of metaphors in organizational science. Academy of Management Review, 16(3), 566-585.

Ulri, B., \& Ulri, D. (2000). Project management in North America: Stability of the concepts. Project Management Journal, $31(3), 33-43$

Verzuh, E. (1999). The fast forward MBA in project management. New York: John Wiley \& Sons, Inc.

Wacquant, L., J. D. (1993). Positivism. In W. Outhwaite, T. Bottomore \& W. Cuthwaite (Eds.), The Blackwell dictionary of twentieth century social thought. Oxford, UK: Blackwell Publishers, Ltd.

Weick, K. E. (1995). What theory is not, theorizing is. Administrative Science Quarterly, 40(3), 385-390.

Wiggins, R. R., \& Ruefli, T. W. (2002). Sustained competitive advantage: 'Temporal dynamics and the incidence and persistence of superior economic performance. Organization Science, 13(1), 82-104

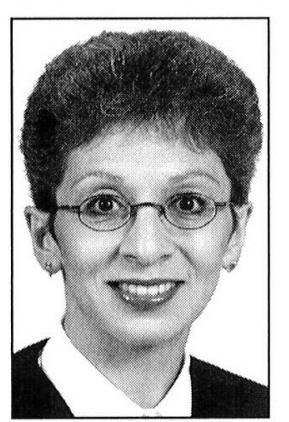

DR. KAM JUGDEV, Assistant Professor of Project Management and Strategy in the MBA program at Athabasca University in Alberta, has extensive university teaching experience in online and traditional formats. She has over 12 years of experience as a senior project manager in public and private sector organizations. Kam's current areas of research include project management as a source of competitive advantage, and the Resource-Based View of the Firm as it applies to project management.

Kam holds a PhD in Project Management (Engineering) from the University of Calgary, a Master of Engineering in Project Management (Civil Engineering, Calgary), a Master of Health Services Administration (Alberta) and two undergraduate science degrees. She has over 25 publications, some of which are in PM Network, Project Management Journal, and the International Journal of Project Management. Kam is also a reviewer for the International Journal of Project Management. As a member of the Project Management Institute, Academy of Management, Strategic Management Society, Administrative Sciences Association of Canada, and the Western Academy of Management, Kam actively contributes to the advancement of academic and professional communities of management practice. 